\title{
Interaction in the Concept \\ of Autonomous Language Learning
}

\author{
Olga V. Putistina* \\ Murmansk State Humanities University \\ 15 Kapitana Egorova Str., Murmansk, 183038, Russia
}

Received 24.02.2015, received in revised form 24.03.2015, accepted 16.05.2015

The study focuses on the role of interactive activities in the process of developing students' autonomy in language learning. The research into the problem of interaction in learner's autonomy involves two aspects: the elaboration of the theoretical grounds for encouraging interaction in autonomous language learning and some practical evidence of exploring those perspectives by empirical means within the communicative and cognitive approach. The article outlines the structure and the constituents of autonomy in language learning, reveals both the universal and the individual components of language acquisition and shows how important these components are for the modern understanding of communicative competence in language learning. The study emphasizes the idea that communicative and cognitive skills that constitute a student's autonomy in language learning are triggered in real communication only through their use in the interaction and cooperation with partners. The concept of interactive autonomous learning is based on the theoretical consequences of a social-interactive view of cognition, learning and language and the idea that autonomy and independence in learning must always be supported by interdependence and collaboration with other learners.

Keywords: autonomy; interaction; communication.

DOI: 10.17516/1997-1370-2015-8-9-1919-1925.

Research area: philology, pedagogy.

\section{Introduction}

A number of researches are devoted to the analysis of the notions "autonomy" and "interaction" in education and in language learning (P. Benson , P. Candy, L. Dam, L. Dickinson, H. Holec, N. Koraykovtseva, D. Little, L. Trofimova, E. Solovova, etc.). There have been formulated the basic principles to defining autonomy and developing autonomous learning. Researchers have outlined the most effective ways of organizing interaction in language classes. The development of autonomous and interactive skills is required by the modern standards and programs of language learning. But the problem that still contains some contradictions is: How can autonomous language learning be interactive? Don't the terms "autonomy" and "interaction" oppose each other? How can they be developed in one and the same teaching-learning environment?

(C) Siberian Federal University. All rights reserved

* Corresponding author E-mail address: onitsitup@mail.ru 


\section{Theoretical framework}

The concept of learner autonomy was first addressed in pedagogics at the beginning of the XXth century within the individual humanistic approach in teaching (S. Frene, R. Cousine etc.). In the context of foreign language learning the promotion of autonomy began in the early 1970s in reference to adult learners studying foreign languages for specific purposes (H. Holec, J. Rubin, H. Stern, N. Naiman, A. Todesco etc.). A more visible interest to the concept of autonomy in language learning began to develop in the 1980s when the focus of teachers' and scholars' attention was shifted from the purposes and content of language learning to the methods of teaching and learning.

In Europe the concept of autonomy has been traditionally developed within the field of the communicative and cognitive approaches (W. Littlewood, J. Bruner, W. Rivers etc.) and social-interactive views of cognition, learning and language (L.Dam, D. Little, R. Ravindran, D. Thanasoulas etc.) that are mostly based on L. Vygotsky's theory of the development of higher psychological processes and setting the "zones of proximal development".

In Russia the interest to the concept of autonomy in foreign language learning was determined by the need to innovate the system of language education in Russia and enable learners to emerge into the European educational context in order to compete professionally in the world market. The concept of autonomy in education in Russia is determined by the theoretical framework of the Activity Theory of Learning (P. Galperin, A. Leontiev, L. Vygotskii etc.) the Theory of Speech Activity (N. Jinkin, I. Zimniaia etc.), the communicative and cognitive approach in language teaching (E. Passov, C. Shatilov, A. Schepilova etc.), learner-centered approach in teaching (E. Borzova, A. Hutorskoi, S. Rubinshtein etc.).

\section{Statement of the problem}

Most of the definitions of autonomy are based on the notions of "independence", "individuality", "work done on one's own". The best known definition of autonomy in language learning is that of H. Holec, who defines autonomy as "the ability to take charge of one's own learning" (Holec, 1981:3). The narrow interpretation of autonomy is "based very much on developing strategies, techniques or material $\langle\ldots\rangle$ in order to promote individual selfdevelopment" (Learner Autonomy, 2000:5).

Interactive language learning, on the contrary, is based on the ideas of collaboration and cooperative learning. If the concepts of interactive and autonomous learning are contrasted, it becomes obvious that autonomous learning requires the exercise of learner's individual responsibility for their own learning and readiness to take charge of one's learning, while interactive learning requires the exercise not only of the individual responsibility but of the collective responsibility in solving tasks and succeeding in language learning through the actualization of the collaborative subject in action (Davydov, 1990).

Does it then mean that "autonomy" excludes "interaction" and vice versa? If "autonomy" implies independence, individuality and "interaction" imply interdependence, collaboration and cooperation, how can the development of learner independence be supported by learner interdependence in language learning?

\section{Methods}

The treatment of the problem must be dealt with by the use of a number of research methods:

- the analysis of the research works on this issue in the field of methods of teaching, pedagogics and psychology;

- the diagnostic methods, including questionnaires, expert monitoring and 
observation, evaluation and assessment charts, self-evaluation and self-assessment charts;

- experimental teaching.

\section{Discussion}

The idea that learner autonomy must be supported by human interdependence is rooted in social-interactive views of cognition, learning and language based on Vygotskii's theory. L. Vygotskii argued that higher cognitive functions are internalized from social interaction (Vygotskii, 1999). A lot of Russian and Western psychologists (F. Anseel, T. A. Beer, A. Belov, P. C. Burnett, F. Lievens, O. V. Solov'eva, etc.) then underlined the importance of feedback reactions in communication that are crucial for the effective organization of a person's activity (Belov, 2014). Interaction with others provides wide opportunities for a person to get an effective feedback in communication. As D. Little once wrote: "Because we are social beings our independence is always balanced by dependence; our essential condition is one of interdependence. Total detachment is a principal determining feature not of autonomy but of autism" (Learner Autonomy, 2000:16).

Language learning is impossible without communication. Autonomous language learning also implies communication. Effective and successful communication in its turn depends on the effective use of cognitive and communicative skills and strategies determined by the nature of language learning. At the same time language acquisition is a two-way relation (a complex of procedural skills) between learning and using the language. Thus the language can be acquired only through the exercise of those skills in language use. The capacities that make up language acquisition are procedural, which means that they can be developed only experientially, that is, through practice. Every case of using the language is a potential stimulus for further language learning. So, it is important for the students to feel the motives for learning and using the foreign language in the classroom. The teacher's job in this case is to engage students in the activities that stimulate learning (on one's own) and encourage the use of the target language in communication with others.

The monitoring and the observation of English classes in Russian schools show that autonomy-driven language learning is mostly organised through the activities in Reading (textbooks, magazines, Internet resources etc.), Listening (films, music, academic listening tasks etc.), Writing (academic writing, e-mails etc.). Autonomous Speaking practice in the conditions of the Russian educational environment is rather limited. It is mostly performed through preparatory work for further individual speaking practice in the classroom usually in the form of retelling texts, or acting out dialogues or answering the questions on the text. But language learning can not be regarded as a cognitive task only. Learners must reflect on their learning in terms of the language input to which they are exposed, or the optimal strategies they need to achieve the goals. But the success of language learning is contingent on the learners' stance towards the possibility to use what they've learned in real communication and sharing it with others. While solving communicative tasks learners must feel the need and the desire to contribute their own ideas, knowledge and skills to the collaborative performance.

The language is both the tool of communication and the tool of cognition. This thesis corresponds with the general understanding of the communicative competence which comprises the knowledge of the language as well as the ability to use it in communication. Today within the communicative and cognitive approach to language teaching shared by many researchers 
and scholars in Russia (N. Baryshnikov, I. Bim, N. Galskova, A. Shchepilova etc.) the process of forming the adequate conceptions of linguistic phenomena and the development of communicative skills of using these phenomena in real communication are treated as equally important.

One of the basic principles of the communicative and cognitive approach is the effective organization of the cognitive actions of learners aimed at solving certain communicative tasks. The human process of cognition and communication has both a universal and an individual element. The universal side of it is reflected in the order in which any cognitive act is performed: presentation-reflection-abstract contextualization-experiment-correction (Mil'rud, Shchepilova, 2003). But this general become more autonomous and confident in their language learning and use.

In the process of teaching an interactive approach is realized through different interactive activities and tasks. Interactive activities are always organized in such a way that they cannot be performed without a partner or partners. Some elements of an interactive activity can be performed independently, but the rest of it is usually done either in pairs, small or dynamic groups.

Interactive activities can be classified according to the principle of distribution of information between partners, cognitive strategies involved and social relationship between the partners in the process of doing the task. Some typical examples of interactive activities are shown in the table below.

\begin{tabular}{|l|l|l|l|}
\hline \multicolumn{1}{|c|}{$\begin{array}{c}\text { Distribution of } \\
\text { information }\end{array}$} & \multicolumn{1}{|c|}{ Cooperation } & \multicolumn{1}{c|}{ Combination } & \multicolumn{1}{c|}{ Transfer } \\
\hline Cognitive strategies & $\begin{array}{l}\text { Reasoning, } \\
\text { argumentation, } \\
\text { sequencing, } \\
\text { hypothesizing, critical } \\
\text { thinking, summarizing }\end{array}$ & $\begin{array}{l}\text { Comparison, contrasting, } \\
\text { singling out, rating, } \\
\text { judging, identifying, } \\
\text { argumentation }\end{array}$ & $\begin{array}{l}\text { Interpreting, reasoning, } \\
\text { generalizing, explaining, } \\
\text { exemplifying, eliciting }\end{array}$ \\
\hline Social relationship & Equality & $\begin{array}{l}\text { Equality, mutual } \\
\text { dependence }\end{array}$ & $\begin{array}{l}\text { Mutual dependence, } \\
\text { individual performance }\end{array}$ \\
\hline Typical examples & $\begin{array}{l}\text { Discussions, buzz groups, } \\
\text { brainstorming, role plays }\end{array}$ & $\begin{array}{l}\text { jigsaw activities, opinion } \\
\text { polls, information gaps, } \\
\text { mind-mapping }\end{array}$ & $\begin{array}{l}\text { Role plays, interviews, } \\
\text { reports with follow-up } \\
\text { activities, micro-teaching }\end{array}$ \\
\hline
\end{tabular}

scheme is realized each time individually by a person with the help of individual cognitive strategies. So if the teacher is aimed at developing students' communicative competence he should first of all teach them to be autonomous and flexible in the use of different cognitive and communicative strategies in solving communicative tasks. The development of these skills and strategies is enhanced if the students get involved in different kind of interaction because it gives them a chance to carry more responsibility for what they do, to practice their skills in communication with the others and thus
The involvement of students in the interactive activities must be performed step by step in accordance with the principle of the gradual increase of the free practice of the language. If the students are not very much familiar with these kind of activities or are not used to working in collaboration with others, in pairs or small groups, the interaction must first take place in the form of the strictly controlled practice in the use of the language. It could be, for example, the organization of the roleplay with the strict distribution of roles and the prompt cards. Then the teacher must gradually 
loosen the control and move on from partially controlled activities to free practice activities, when students would be able to plan, organize, control, correct, evaluate and assess their own work.

Interactive activities make it possible for the learners to realize themselves as subjects of their own learning process, create the conditions for developing learners' creativity and provide a productive character of the educational process. Through the involvement in the interactive activities the students develop the qualities of active learners and users of a foreign language capable of taking independent decisions and cooperating with others in communication. All these qualities constitute the basis of autonomy in language learning.

\section{Conclusion}

Taking into consideration the socialinteractive view of cognition, learning and language based on L.Vygotskii's socio-cultural theory of learning new levels of autonomy in language learning are achieved only through interaction with others in the real process of communication when the language is not just learned but used as well. New levels of autonomy can only be achieved by moving through the phases of dependence and interdependence. Interactive activities must be organized according to the principle of the gradual increase of the free practice of the language use that lets students move from the phases of dependence to the phases of interdependence and responsible independence. Thus autonomy in learning and using a language develops only through practice. This also creates the ground for the socialization of a person and developing in him/her the qualities useful for the future life and professional advancement because the students find themselves beyond the limits of their immediate educational environment.

\section{References}

1. Belov, A.V. (2014) Rol' obratnoi sviazi v obschenii: osnovnye napravleniia issledovanii v zarubezhnoi sosial'noi psihologii [Feedback in communication: Principal lines of research in international social psychology]. Voprosy psychologii, (3), 149-157.

2. Borzova, E.V. (2007) Obshchaia harakteristika inoiazychnogo lichnostno orientirovannogo obrazovaniia na starshei stupeni srednei shkoly [The general characteristic of the learner-centered education in foreign language teaching in senior forms of the secondary school]. Izvestiia Rossiiskogo gosudarstvennogo universiteta im. A.I. Gertsena, (4), 163-170.

3. Boud, D., Molloy, E. Rethinking models of feedback for learning: the challenge of design (2013) Assessment \& Evaluation in Higher Education, 38(6), pp.698-712. doi: $10.1080 / 02602938.2012 .691462$

4. Davydov, V.V. (1990) Deiatel'nostnaia metodika obucheniia inostraanym iazykam [Activity methods of teaching foreign languages]. Moscow, Vyssh. shk, 1990. 175 p.

5. Devos, G., Tuytens, M., and Hulpia, H. Teachers' Organizational Commitment: Examining the Mediating Effects of Distributed Leadership (2014) American Journal of education, 120(2), pp. 205-231. doi: 10.1086/674370, available at: www.jstor.org/stable/10/1086/674370

6. Faircloth, S.C., and Tippeconnic III, J.W. Leadership In Indigenous Education: Challenges and Opportunities For Change (2013) American Journal of Education, 119(4), pp. 481-486. doi: 10.1086/671017, available at: www.jstor.org/sable/10/1086/671017 
7. Hill, H.C., Umland, K., Lithe, E., and Kapituda, L.R. Teacher Quality and Quality Teaching: Examining the Relationship of a Teacher Assessment to Practice (2012) American Journal of Education, 118(4), pp. 489-519. doi: 10.1086/666380, available at: www.jstor.org/stable/10.1086/666380

8. Holec, H. (1981) Autonomy and Foreign Language LearningOxford: Pergamon

9. Koriakovtseva, N.F. Sovremennaia metodika organizatsii samostoiatel'noi raboty izuchaiushchih inostannyi iazyk [Modern methods of organizing learners' independent work in language learning]. Moscow, ARKTI, 2002. 176 p.

10. Learner Autonomy, Teacher Autonomy: Future Directions. London, Longman, 2000. 138 p.

11. Leont'ev, D.A. (2014) Psikhologiia vybora. Chact' II. Lichnostnye predposylki I lichnostnye posledstviia vybora [Psychology of choice. Part II. Personal causes and personal consequences of choice]. Psikhologicheskii zhurnal, 35(6), 56-67.

12. Lokalova, N.P., Dregnina A.M. (2014) Vliianie kognitivnogo razvitiia na formirovanie vnutrennego motiva uchebnoi deiatel'nosti [Influence of cognitive development on formation of the inner motive of learning activity]. Voprosy psikhologii, (5), 15-33.

13. Mil'rud, R.P., Maksimova, I.R. (2000) Sovremennye kontseptual'nye printsipy kommunikativnogo obucheniia inostrannym iazykam [Modern conceptual principles of communicative foreign language teaching]. Inostrannye Iazyki v Shkole, (5), 17-22.

14. Nikolayev, A.Ya., Seryogin, K.S., Strizhova, E.A., Evdokimenko, A.S. (2014). Sotsial'nopsykhologicheskie aspekty formirovaniya kul'tury samoobuchaiushcheisia organizatsii [Social psychological aspects of formation of the culture of a self-teaching organization]. Voprosy psikhologii, (6), 44-52.

15. Shchepilova, A.V. (2003). Kognitivnyi printsip v obuchenii vtoromu inostrannomu iazyku: $\mathrm{k}$ voprosu o teoreticheskom obosnovanii [The cognitive principle in teaching the second foreign language: towards the problem of the theoretical basis]. Inostrannye Iazyki v Shkole, (2), 4-11.

16. Shchukina, M.A. (2014). Napravlenie issledovanii samorazvitiia lichnosti v sovremennoi zarubezhnoi psikhologii [Research of personality self-development in contemporary international psychology]. Voprosy psikhologii, (4), 94-106.

17. Solovova, E.N. (2004). Avtonomiia uchashchihsia kak osnova razvitiia sovremennogo nepreryvnogo obrazovaniia lichnosti [Learners' autonomy as the basis of developing the modern system of the lifelong education]. Inostrannye Iazyki v Shkole, (2), 11-17.

18. Vygotskii, L.S. (1999). Myshlenie I rech [Thinking and Speech]. Moscow, Labirint, 1999. $350 \mathrm{p}$.

19. Walker, M. The quality of written peer feedback on undergraduates' draft answers to an assignment, and the use made of the feedback (2015) Assessment \& Evaluation in Higher Education, 40(2), pp. 232-247. doi: 10.1080/02602938.2014.898737

20. Wendy, L.B., Stephen, M.F., Salas, E. Developing the Future Workforce: An Approach for Integrating Interpersonal Skills Into the MBA Classroom, Academy of Management Learning \& Education, 2014, June 1, available at: http://amle.aom.org/content/13/2/171 


\section{Интерактивность в концепции развития \\ автономии учащихся \\ в процессе обучения иностранному языку}

\section{О.В. Путистина}

Мурманский государственный гуманитарный университет Россия, 183038, Мурманск, ул. Капитана Егорова, 15

В статье рассматривается проблема использования интерактивых заданий в процессе развития автономии обучающихся на занятиях по иностранному языку. Приведен обзор основных научных подходов, составляющих теоретическую базу исследования и позволяющих обосновать целесообразность использования элементов интерактивного обучения в формировании автономии учащихся, а также представлены выводы по результатам практического использования интерактивных заданий в ходе развития автономии учащихся. В статье освещаются универсальность и индивидуальность иноязычной коммуникативнокогнитивной деятельности и выделяются умения и стратегии, составляющие автономию, которые формируются в ходе коммуникативной интерактивной деятельности.

Ключевые слова: автономия, интерактивность, коммуникация.

Научная специальность: 10.00.00 - филологические науки, 13.00.00- педагогические науки. 